\title{
IAMJ
}

INTERNATIONAL

AYURVEDIC

MEDICAL JOURNAL

Review Article

ISSN: 2320-5091

Impact Factor: 6.719

\section{USHNODAKA AS A DAILY ROUTINE}

\section{Shashikala Kurbet ${ }^{1}$, Pratibha Kulkarni ${ }^{2}$, Raviraj Kurbet ${ }^{3}$}

${ }^{1} 2^{\text {nd }}$ year PG Scholar, Dept of Kriya Shareera, SDM college of Ayurveda and Hospital, Hassan, Karnataka, India ${ }^{2}$ Proffesor and HOD, Dept of Kriya Shareera, SDM college of Ayurveda and Hospital, Hassan, Karnataka, India

${ }^{3}$ Assistant Professor, Dept of Shareera Rachana, Govt Ayurveda medical college, Bengaluru, Karnataka, India

Corresponding Author: dr.shashikalamay18@gmail.com

https://doi.org/10.46607/iamj2809052021

(Published Online: May 2021)

Open Access

(C) International Ayurvedic Medical Journal, India 2021

Article Received: 30/04/2021 - Peer Reviewed: 06/05/2021 - Accepted for Publication: 07/05/2021

Check for updates

\begin{abstract}
Ayurveda is the 'science of life' mainly aims at positive health by preventing a person from getting any disease as well as treat the diseased person. A balanced state of Tridosha, Dhatus, Mala, Agni etc helps to keep one's life healthy. Any disturbances in these factors will leads to ill health. So, in present era we should plan accordingly and should follow strictly Dinacharya, Ritucharya, and Ratricharya to maintain the proper health. Ayurveda has described some rules for Ahara, Vihara and Jalasevana. Acharya Sushrutha told that the life of living creature is water itself. Water is one of the pancha mahabhuta which is vital for the creatures. Trishna is one among non-suppressible natural urge described in our science. Ayurveda recommends the intake of cold as well as warm water based on the body condition. Our Acharyas explained the benefits of Ushnambu, Shitambu, and their qualities, and we should consider the indications and contra indications of water to maintain the Avikrutavastha of Tridosha and Agni. 'Ushnodaka 'means warm water but here water should be boiled properly not just heated. Generally, Udaka is used as Anupana for Ahara, but Ushnodaka has its own specialty as an Anupana for Ahara, for Aushadhi, and it can be used in particular Vyadhivastha. Thus, Ushnodaka plays an important role in Swastha Samrakshana as well as Vikara Prashamana. So here I made an attempt to discuss the importance of Ushnodaka as a daily routine.
\end{abstract}

Keywords: Ushnodaka, Swastha, Anupana, Jalasevana, Agni, Tridosha, Vyadhi, Daily routine. 


\section{INTRODUCTION}

According to Ayurveda a balanced state of Dosha, Dhatu, Mala, and Agni and Prasannata of Atma and Indriya is considered as health ${ }^{1}$. Our science explained two methods for maintenance of health, they are Swasthasya Swastha Rakshanam i.e. maintaining health by adopting proper preventive measures and Aturasya Vikara Prashamana i.e. curing of disease by giving suitable treatment for the ailment ${ }^{2}$. Water is most essential part of our life for our survival. There are several references where Acharyas mentioned that Ushnodaka Pana also has equal importance in regulation of health. Acharyas mentioned certain regimens that should be followed regularly for preventing diseases and to keep health, such as, Dinacharya, Ratricharya, Ritucharya and Sadvritta palana. And also, in Ayurveda there are some rules for Aharasevana and Jalasevana. Similarly, in swastha health is maintained normally by food preparations and rogi it is maintained by medicinal preparations. Ushnodaka means warm water but here water should be boiled properly not just heated. Kalpana Vijnana is having very important role in health. The term Kalpana originated from the root "KRIPU SAAMARDHYE" meaning that which make a substance potent or active ${ }^{3}$.Ushnodaka is one which comes under Upakalpana of Kwatha Kalpana ${ }^{4}$, here Kwatha refers to boiling which means mere heating is not sufficient. Ushnodaka is used as both Anupana and Sahapana depending upon the basis of drug, patient and disease. Ayurveda recommends warm water instead of cold water because cold water and cold items can weaken the digestive power as it slowdowns the digestive process.

\section{Importance of Ushnodaka}

In Ayurveda Ushnodaka is mentioned in various disease. Jwara is considered as Amashaya Samuttha Vyadhi and in Jwara there is a need of Deepana pachana Dravya due to Anubhandha of Ama. Drinking Ushnodaka is Hita (wholesome) for those suffering from Vataja and Kaphaja Jwara because that will promotes Agni due to its Deepana, Pachana property, and clears the Srotavaroda, it disintegrates Kapha, promotes appetite and sweating and carries Pitta and Vata in their normal site ${ }^{5}$. For Paittika Jwara water should be first boiled with Tikta Dravyas and allowed to cool for some time for drinking.

\section{Method of preparation:}

The water which is reduced after boiling up to $1 / 8^{\text {th }}$ part, $1 / 4^{\text {th }}$, and $1 / 2$ of its original quantity is called $U_{s h}$ nodaka ${ }^{6}$.

Ideal Ushnodaka: Properties of water will also depend upon its reduction. The water devoid of foam or froth and which is pure, still and light, when boiled up to $1 / 4^{\text {th }}, 1 / 3^{\text {rd }}$ or $1 / 2$ reduced is ideal. From the three varieties the ideal one shall be selected according to the Desha and Ritu ${ }^{6,7}$

Srita Shita Jala - Water which is boiled well and then cooled is the ideal one ${ }^{8}$. Which is Tridoshahara and useful in all the Ritus (seasons).

Paryushita Jala - The water which has been kept for more than a day and should never be given to thirsty person.

One should not use water which is kept for a long period and which is Amla because it increases Pitta. It is not good for one who suffering from thirst, intoxication diseases and pitta disorders, such water is considered as Agrahyajala ${ }^{9}$.

The water which is kept overnight is also not good for health and it should not be used ${ }^{10}$.

\section{Gunas of Ushnodaka:}

It is having Laghu Guna (light), Achha (clear) and Shuddha (pure).

It is having Deepana property and also possess Bastishodhana action.

Ushnodaka is able to decrease Kapha, Vata and Medha ${ }^{7}$. 
Table 1: Guna and karma of Ushnodaka

\begin{tabular}{|c|c|}
\hline Acharyas & Lakshanas \\
\hline Charaka $^{5}$ & Vatahara, Kaphahara, Agni Vardhaka, \\
\hline Sushrutha ${ }^{11}$ & Vatahara, Kaphahara, Medohara, Amahara, Deepana, Bastishodhana \\
\hline Astang hridaya ${ }^{7}$ & Vatahara, Kaphahara, Amahara, Deepana, Bastishodhana \\
\hline Yoga ratnakara ${ }^{10}$ & Vatahara, Kaphahara, Medohara, Deepana \\
\hline Bhavaprakasha ${ }^{12}$ & Vatahara, Medohara, Amahara, Pachana, Bastishodhana \\
\hline
\end{tabular}

Table 2: Relation of Jalapana and its effects on body ${ }^{7}$

\begin{tabular}{|l|l|}
\hline Jalapana & Effects on body \\
\hline Before food & Lean \\
\hline In between food & Medium \\
\hline After food & Obese \\
\hline
\end{tabular}

Table 3: Action of Ushnodhaka on Tridosha based on reduction

\begin{tabular}{|c|c|c|}
\hline Dosha predominance & Reduction acc to Sushrutha $^{\mathbf{1 3}}$ & Reduction acc to Sharanghadara $^{\mathbf{1 4}}$ \\
\hline Vataghna & $1 / 4$ th & $3 / 4$ th \\
\hline Pittaghna & $1 / 2$ & $1 / 4$ th \\
\hline Kaphaghna & $3 / 4$ th & $1 / 2$ \\
\hline
\end{tabular}

Table 4: Benefits of Ushnodaka according to season

\begin{tabular}{|l|l|l|}
\hline Reduction & Yogaratnakara $^{15}$ & Madana Vinoda $^{16}$ \\
\hline $1 / 2$ & Sisira, Vasanta, Greeshma & Hemanta, Sisira, Varsha \\
\hline $1 / 4$ th & Hemanta Ritu & Greeshma, Sharat \\
\hline $1 / 8$ & Sharat, Pravrit & $---{ }^{---}$ \\
\hline
\end{tabular}

Srita Sheeta jala (boiled and cooled water) is Laghu and Tridosha Shamaka and so it is always suitable in all Ritus.

\section{Use of Ushnodaka based on prakriti ${ }^{17}$}

1) In Kapha Prakriti person: Kapha prakriti person can sip the water hot, this reduces the toxic build up.

2) In Pitta Prakriti person: Pitta Prakriti person should cool the boiled water to body temperature and drink with or after food. This Prakriti person should take carefully more hot items or drinks.

3) In Vata Prakriti person: Vata Prakriti person should take drink warm water, and they should avoid hot and cold water. Their cool and dry skin needs warm temperature water for Srotoshodhana and for Amahara action.

Rate of absorption of regular water and boiled water $^{17}$
1) Regular water - Takes about 6 hours for absorption if every channel is clear

2) Boiled and cooled water - It takes about 3 hours to be absorbed and helps to open the channels.

3) Hot herbarized water - It takes about $1 \frac{1}{2}$ hours due to sharpness of Agni and herbs.

Action of intake of Ushnodaka at night ${ }^{10}$

Ushnodaka which is administered in the night helps to relieve constipation and does Vatanulomana Karma and effective in Ajeerna condition.

\section{Indications of Ushnodaka ${ }^{18}$ :}

Generally Ushnodaka can be used in several conditions like Jwara (fever), Mandagni (weak digestive power), Pratisyaya (rhinitis), Netraroga (eye disorders), Kustha (skin disorders), Galagraha, Kasa (cough), Shwasa (cold), Parshwashoola (pain in flanks), Pinasa (running nose), Adhmana (distension of abdomen), Hikka (hiccups), Trishna (thirst), Shoola (pain), and Vatakaphaja rogas. 


\section{Contra indications of Ushnodaka ${ }^{18}$ :}

Ushnodaka which is prepared during daytime is contraindicated at night and the Ushnodaka which prepared during night is contraindicated for use during the following day as it turns Guru (heavy for digestion) in both the conditions.

Boiled water can be used throughout the day, but it should not be kept overnight, since its therapeutic properties expire.

\section{Dose:}

It is not intended to administer as medicine

To quench thirst is the main purpose and it can be taken in sufficient quantity.

\section{Indications of Shita Jala ${ }^{18}$}

Glaani (tiredness), Moorcha (giddiness), Chardi (vomiting), Shrama (weakness), Bhrama (vertigo), Trishnoshna (excessive thirst), Raktapitta (bleeding disorders), Visha (poisoning).

\section{Contraindications of Shita Jala $^{18}$}

Navajwara, Pratisyaya, Galagraha, Kasa, Shwasa, Grahani, and in Vatakaphaja Roga.

\section{Ushnodaka as Anupana}

Any Dravyas (substance) or drinks which are consumed along with or followed by main Dravya (drug) or food is called as Anupana. As an Anupana, water is considered as best Anupana because it is the chief source of all the tastes. It is accustomed to all living beings and possess the properties of sustaining life ${ }^{19}$. Acharya Sharanghadara mentioned that, just as a drop of oil quickly spreads over the water, in the same way the medicine spreads in the body by the effect of Anupana.

Acharya sushrutha mentioned that Antariksha Jala (rainwater) is best Anupana among all. Acharya Vagbhata also stated jala as Shrestha Anupana.

In general, Anupana brings about refreshment, pleasure, energy, nourishment, satisfaction and helps in breakdown, digestion, softening, proper assimilation and instant diffusion of food and diet consumed ${ }^{20}$. Anupana is decided based on Ahara, Aushadhi, Roga, Rogi, Dosha etc. factors.

Ushnodaka as Anupana along with Aushadhi is more beneficial as Acharya sharanghadara mentioned that Ushnodaka helps drug to travel and reach to its target faster and thus by this Ushnodaka acts as a catalyst which makes the drug work more efficiently.

\section{Physiological action of Ushnodaka}

According to Ayurveda balanced state of Tridosha, Dhatus, Mala and Agni etc. is called as swastha. Any disturbance in these factors will leads to vyadhi utpatti. Ushnodaka is having mainly Deepana, Pachana property which causes Srotoshodhana of our body. And also helps to remove the Mala and Dosha in the Srotas and clears the Srotas. Ayurveda explained Dhatu Poshana Nyayas, in that the Poshana (nourishment) of the successive Dhatu depends on the different theories given by the Acharya. Due to intake of Apathya Ahara Vihara these Srotas gets blocked which leads to incomplete nourishment of Dhatus, so in this condition Ushnodaka helps to remove the blockage and thus it nourishes the Dhatus, by that it will maintains the proper health. When these Srotas get blocked due to the intake of $A p$ athya Ahara Vihara the movements of Doshas in the body get disturbed causing imbalance in the Doshas resulting in the disturbed physiological actions and thus leads to ill health.

\section{DISCUSSION}

In present era the fast life forces people to take fast foods and soft drinks. Instead of taking such cold drinks it is better to take well boiled and cooled water or water boiled with Tiktha Dravyas or with medicinal dravyas will be effective as well as good for health. While boiling we can make water free from all the pathogens, free from harmful chemicals, pleasant tastes and useful in maintenance of health. Warm water stimulates hunger, helps in digestion, good for throat and it cleanses the urinary bladder, relieves hiccup, flatulence, helps in aggravation of Vata and Kapha and also it is ideal for those who suffering from cold, cough and fever. Ushnodaka helpful in healthy individuals too. One should not drink it in hurry, always drink warm water slowly and in small quantities when one feels thirsty. As Mandagni is the main root cause for all the diseases, because of its Agni Deepana property Ushnodaka is having very important role in Mandagni. It reduces the risk of constipation by supporting regular bowel move- 
ments, it also helps in body detoxification. So pure water is considered as the life of all living creatures, hence Ushnodaka is taken into consideration.

\section{CONCLUSION}

In Ayurveda the health benefits, importance of Ushnodaka and various method of preparation of Ushnodaka are mentioned. Ushnodaka not only helps to maintain healthy status of a person but also helps the medicines to work more effectively when it is taken as Anupana. If one should follow Ritucharya and if person is taking Ushnodaka according to season he can maintain the equilibrium state of Tridoshas. Deepana and Pachana property of Ushnodaka increases the digestive fire, Ushnodaka not only quenches the thirst but also helps in maintenance of health of an individual, clear the body channels. Acharya Sushrutha mentioned the Medohara property of Ushnodaka which helps to remove the excessive fat which is accumulated in our body. Ushnodaka is a simple and effective substance which is having excellent effect on our body. Ushnodaka which can be prepared instantly and used as a part of daily regimen in present era to maintain health.

\section{REFERENCES}

1. Acharya YT. Susruta Samhita by Susruta with Nibandhasangraha teeka of Dalhanacharaya, Varanasi. Chowkhamba Orientalia; Reprint2013. p.110

2. Acharya YT. Charaka Samhita by Agnivesa with Ayurveda deepika teeka of Chakrapanidatta. Varanasi. Chaukhamba Surabharati Prakashana; Reprint 2011.p.187

3. Kanta deva, R.R. Shabdhakalpadruma; $3^{\text {rd }}$ ed. Varanasi: Chaukhamba Sanskrit series;1967; Vol.2. p.64

4. Kanta deva, R.R. Shabdhakalpadruma; $3^{\text {rd }}$ ed. Varanasi: Chaukhamba Sanskrit series;1967; Vol.2. p.138

5. Acharya YT. Charaka Samhita by Agnivesa with Ayurveda deepika teeka of Chakrapanidatta. Varanasi. Chaukhamba Surabharati Prakashana; Reprint 2011.p.410

6. Acharya Y T. Susruta Samhita by Susruta with Nibandhasangraha teeka of Dalhanacharaya, Varanasi. Chowkhamba Orientalia; Reprint 2013.p.200

7. Kunte A M. Astanga Hrudaya of Vagbhata. Varanasi: Chaukhamba Sanskrit Sansthana; Reprint 2012.p.65S

8. Acharya Y T. Susruta Samhita by Susruta with Nibandhasangraha teeka of Dalhanacharaya, Varanasi. Chowkhamba Orientalia; Reprint 2013.p.332
9. Acharya YT. Charaka Samhita by Agnivesa with Ayurveda deepika teeka of Chakrapanidatta. Varanasi.Chaukhamba Surabharati Prakashana; Reprint 2011.p.425

10. Tripathi I, Tripathi D S. Yogaratnakara. $1^{\text {st }}$ ed. Varanasi: Krishnadas academy; 1998; p.75

11. Acharya Y T. Susruta Samhita by Susruta with Nibandhasangraha teeka of Dalhanacharaya, Varanasi. Chowkhamba Orientalia; Reprint 2013.p.(SU.45/39)

12. Bhavaprakasha, madhyam, cha 1, verse 63

13. Acharya Y T. Susruta Samhita by Susruta with Nibandhasangraha teeka of Dalhanacharaya, Varanasi. Chowkhamba Orientalia; Reprint2013. p.200

14. Saranghadara, Saranghadara Samhita, Dipika Commentary. $5^{\text {th }}$ ed. Varanasi: Chaukamba Orientalia;2002; p. 166

15. Tripathi I, Tripathi D S. Yogaratnakara. $1^{\text {st }}$ ed. Varanasi: Krishnadas academy;1998;p.74

16. Ramadevi R. A textbook of Bhaishajya kalpana. Cherpulassery:Perfect publications;2006;p.154

17. Links S. Ushnodaka: extension of water therapy (Internet). India Divine.org.2004 Jun (october2015). Available from http://www.indiadivine.org/content/topic/1158527-ushnodaka -extension -of-water therapy/.

18. P. Gyanendra, Bhaishajyaratnavali Pradhamakhandam; Jwaradhikaara:3, Varanasi:2005 p.71-73

19. Vagbhata. Sutrasthana: Astanga Samgraha, saroj Hindi commentary.Reprnt ed.Varanasi:Chaukambha Surabharati parakashana;2001;p.221

20. Acharya YT. Charaka Samhita by Agnivesa with Ayurveda deepika teeka of Chakrapanidatta. Varanasi. Chaukhamba Surabharati Prakashana; Reprint 2011.p.172

\section{Source of Support: Nil \\ Conflict of Interest: None Declared}

How to cite this URL: Shashikala Kurbet et al: Ushnodaka As A Daily Routine. International Ayurvedic Medical Journal \{online\} 2021 \{cited May, 2021\} Available from: http://www.iamj.in/posts/images/upload/1111_1115.pdf 